\title{
NILAI MASJID JAMI KALI PASIR SEBAGAI SEBUAH BANGUNAN CAGAR BUDAYA: PENGAMATAN SEORANG PEJALAN KAKI
}

\author{
Feby Hendola \\ Program Studi Arsitektur Fakultas Teknologi dan Desain Universitas Pembangunan Jaya \\ Jl. Cendrawasih Raya Blok B7/P Bintaro Jaya, Sawah Baru, Ciputat, Tangerang Selatan \\ *Email: feby.kaluara@upj.ac.id
}

\begin{abstract}
Masjid Jami Kali Pasir (MJKP) is believed as the oldest mosque in Tangerang. It is located at Pasar Lama-Kali Pasir heritage site, near old Chinese settlements. In 2011 MJKP was legitimated as an architectural heritage by government of Tangerang City regardless its unnoticeable appearance and its lack of accurate historic and architecture documentary. Nevertheless the board of MJKP's welfare mosque has tried to conserve its original parts. These facts show that MJKP has significant meaning despite its status, as an architectural heritage, is questionable. Based on this background, this writing is an attempt to know what value that MJKP contains apart from its valid historical data by experiencing its architecture and spatial conditions around it from a pedestrian's viewpoint. Pictures of walking sequence to MJKP and interview with visitors and local people about their perception on Pasar Lama-Kali Pasir heritage site and the mosque were used to study the value. After analyzing the data with Kevin Lynch's theory about 'sense' dimension, the study revealed that MJKP's spiritual value could maintain its existence even though its physical appearance was not significant. In conclusion, the spiritual value might be essential in architectural conservation to know why an architectural heritage that has lack of historic documentary and unnoticeable appearance, such as MJKP, needs to be preserved.
\end{abstract}

Keywords: Architectural Conservation, Architectural Heritage, Urban Sequence, Preservation, Spiritual Value.

\section{PENDAHULUAN}

Bangunan adalah salah satu fitur yang dapat memberikan pengalaman ruang tersendiri pada suatu kota. Oleh karenanya, arsitektur, sebagai ranah yang menampung banyak persoalan konstruksi dan makna suatu bangunan, menjadi krusial dalam pengembangan kota.

Salah satu persoalan yang tidak luput ditilik dalam ranah arsitektur adalah bangunan cagar budaya. Dengan nilai sejarah dan estetika yang terkandung di dalamnya, bangunan cagar budaya kerap dipertahankan tidak hanya untuk menghargai masa lampau suatu kota, tetapi juga memberikan pengalaman ruang yang emosional bagi warga kota. Terkait hal ini Feilden, dalam Conservation of Historical Buildings, menyatakan bahwa "[b]angunan bersejarah memiliki nilai arsitektural, estetika, historis, dokumenter, arkeologis, ekonomi, sosial, bahkan politis dan spiritual atau simbolik; namun dampak pertama yang dirasakan selalu emosional, karena ia merupakan simbol dari identitas dan kesinambungan budaya kita..." (Feilden, 2003). Dapat dikatakan bahwa peran bangunan cagar budaya atau bangunan bersejarah adalah penting dalam memberikan kesan keberlanjutan dan identitas budaya suatu kota.

Dengan alasan di atas, konservasi bangunan cagar budaya menjadi proses yang perlu dipelajari pula dalam ranah arsitektur. Namun, mengonservasi bangunan tidak dapat dimulai tanpa meninjau urgensi suatu bangunan untuk dipelihara. Di Indonesia sendiri terdapat Undang Undang Republik Indonesia No. 11 Tahun 2010 pasal 5 yang menyatakan bahwa bangunan yang dianggap cagar budaya adalah yang memiliki umur dan masa gaya paling singkat 50 tahun; mewakili arti khusus bagi sejarah ilmu pengetahuan, pendidikan, agama, dan/atau kebudayaan; memiliki nilai budaya pagi penguatan kepribadian bangsa. Undang- 
undang ini kemudian diadopsi menjadi kriteria yang lebih spesifik oleh pemerintah kota-kota di Indonesia, termasuk Tangerang.

Pada 25 Agustus 2011 Pemerintah Kota Tangerang menetapkan beberapa bangunan menjadi cagar budaya, salah satunya adalah Masjid Jami Kali Pasir (Keputusan Walikota Nomor 430/kep.337-Disporbudpar/2011). Masjid ini terletak di bagian kota tua Tangerang, tak jauh dari kawasan pusaka Pasar Lama. Di dalam kawasan ini masih dapat ditemui bangunan-bangunan Tionghoa tua dengan bubungan atap yang khas. Bangunan tua tersebut bersanding dengan bangunan baru, memberikan keragaman pada kawasan yang didominasi oleh fungsi komersial dan residensial ini.

Semenjak penetapan status tersebut, Masjid Jami Kali Pasir menjadi bangunan yang perlu dipertahankan bentuknya, senasib dengan Klenteng Boen Tek Bio yang letaknya tidak jauh dari tempat ibadah umat muslim ini. Keduanya beserta tujuh cagar budaya lainnya direncanakan menjadi destinasi wisata (Kota Tangerang Kenalkan Sembilan Cagar Budaya, 2016). Dengan demikian, Masjid Jami Kali Pasir tidak lagi berfungsi sebagai tempat beribadah saja, tetapi juga menjadi salah satu tujuan turis dari luar Kampung Kali Pasir (Gambar 1).

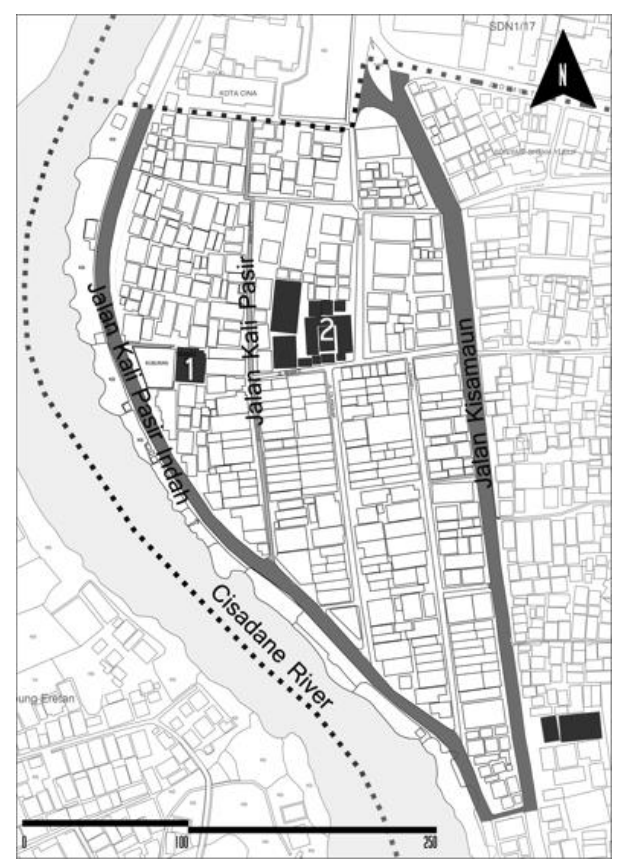

Gambar 1. Posisi Masjid Jami Kali Pasir dan Klenteng Boen Tek Bio

Sumber: Hendola \& Priadi, 2016
Namun, penggolongan bangunan cagar budaya Kota Tangerang tersebut belum dapat diketahui landasan dan kriterianya. Meskipun idealnya penggolongan bangunan cagar budaya menuntut keakuratan sejarah, hasil penelusuran awal penelitian ini justru menunjukkan hal sebaliknya. Menurut Ketua Dewan Kesejahteraan Masjid Jami Kali Pasir (DKM), Pak Sjairodji, ada beberapa versi kisah mengenai sejarah masjid yang juga menampung makam salah satu pengurusnya ini. Kisah yang kerap diceritakan oleh beliau terlampir pada selembar kertas catatan yang terus ia simpan. Menurut catatan tersebut, Masjid Jami Kali Pasir dibangun pada 1700-an. Akan tetapi, Pak Sjairodji juga mengutarakan bahwa beberapa arkeolog dari Bandung menemukan tulisan "1615" pada rangka kayu atap masjid yang membuat mereka berasumsi bahwa masjid ini dibangun pada tahun sesuai dengan angka yang tertera. Pada lain waktu, Pak Sjairodji juga berbincang dengan kawan yang sempat menemukan artikel di internet bahwa pada tahun 1602 masjid sudah dikelola oleh Tumenggung Aria Ramdon, pengurus generasi ketiga Masjid Jami Kali Pasir. Hasil obrolan ini menunjukkan bahwa data terkait sejarah Masjid Jami Kali Pasir masih memerlukan kajian lebih lanjut.

Selain itu, kedekatan lokasi antara Masjid Jami Kali Pasir dengan Klenteng Boen Tek Bio juga dianggap sebagai bentuk toleransi agama. Beberapa artikel bahkan menuliskan, bentuk minaret dan puncak atap masjid mengambil gaya arsitektur Tionghoa sebagaimana lokasinya yang dekat dengan permukiman Tionghoa (Masjid Jami Kalipasir, Bukti Akulturasi dan Kerukunan Beragama, 2014). Terkait hal ini, pihak DKM tidak menemukan referensi atau naskah sejarah yang mengatakan Masjid Jami Kali Pasir merupakan bangunan yang memadukan unsur budaya Tionghoa (Dewan Kesejahteraan Masjid Jami Kali Pasir, 2016). Meski demikian, dugaan dan asumsi tentang gaya arsitektur masjid tersebut tidak dapat dibendung.

Pada sisi lain, Masjid Jami Kali Pasir bukan masjid besar yang mudah diketahui kehadirannya. Masjid Jami Kali Pasir berdiri di antara pemukiman warga yang cukup rapat satu sama lain. Untuk mencapainya perlu melewati gang-gang kecil. Masjid ini juga bukan bangunan dengan halaman luas di sekitarnya. Sisi samping dan belakangnya hanya dipisahkan oleh jalan selebar 1-3 meter dari rumah warga 
sekitar. Sementara bagian depannya dirimbuni pepohonan yang menaungi makam. Minaret masjid adalah bagian masjid yang paling mudah dilihat. Namun, menara setinggi kurang lebih 10 meter ini tetap kurang mencolok apabila dilihat dari Pasar Lama.. Dapat dikatakan, keberadaan Masjid Jami Kali Pasir tidak mudah diketahui oleh pengunjung ataupun warga sekitar Pasar Lama.

Walaupun tidak ada dokumentasi arsitektur yang lengkap dan letaknya tersembunyi, pelestarian bangunan Masjid Jami Kali Pasir tetap dilakukan secara mandiri oleh warga sekitar. DKM cukup yakin praktik konservasi yang dilakukannya mampu melestarikan kehadiran masjid (Lukito, 2017). Apalagi upaya pelestarian tersebut telah dilakukan sejak sebelum status masjid sebagai bangunan cagar budaya disematkan. Dapat dikatakan, Masjid Jami Kali Pasir memiliki makna penting, setidaknya bagi warga sekitar, meskipun kesahihan sejarahnya perlu ditelusuri lebih dalam (Gambar 2).

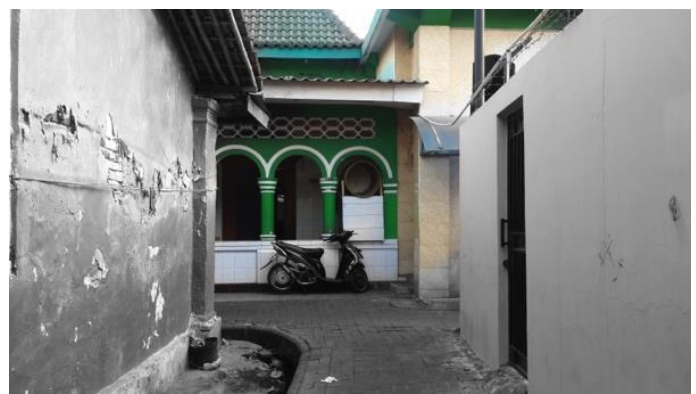

Gambar 2. Masjid yang Tersembunyi

Perdebatan mengenai status dan pelestarian Masjid Jami Kali Pasir sebagai bangunan cagar budaya dapat ditinjau lebih lanjut. Namun, hal tersebut tidak akan berarti tanpa mengetahui nilai yang dikandung oleh Masjid Jami Kali Pasir sendiri bagi para penggunanya, pengunjungnya, ataupun warga yang tinggal di sekitar masjid. Berdasarkan latar belakang ini, penulis hendak mencari tahu nilai yang dapat dicerap dari arsitektur Masjid Jami Kali Pasir saat ini. Penelusuran ini mencakup peran elemen arsitektur masjid, baik yang fisik maupun nonfisik, terhadap persepsi warga dan pengunjung.

Terkait pengaruh bangunan terhadap persepsi manusia dalam mengalami ruang kesehariannya, termasuk di kota, Kevin Lynch dalam The Good City Form, memaparkan salah satu dimensi performa yang perlu ditinjau untuk membentuk kota yang 'baik', yaitu 'sense'.
Dimensi 'sense' adalah pertemuan antara wujud lingkungan binaan dengan proses persepsi dan kognisi manusia (Lynch, 1981). 'Sense' merupakan tolok ukur ruang kota yang dicerap dan diidentifikasi secara jelas. Dimensi ini juga dipengaruhi oleh budaya, status, pengalaman, dan tujuan tertentu pengamat dan penikmat ruang kota.

Perwujudan paling sederhana dari dimensi 'sense' adalah identitas (Ibid). Hal ini muncul karena seseorang dapat mengingat ulang sebuah tempat yang dianggap unik dari yang lainnya. Namun, hal ini tidak terpaku pada pengalaman visual saja. Indera lain juga dapat digunakan untuk membantu seseorang merekam suatu ruang. Keunikan yang dirasakan oleh indera ini dapat menciptakan sense of placeperasaan yang muncul karena adanya sesuatu yang menjelaskan kehadiran sebuah ruang. Tidak hanya tempat, identitas suatu ruang kota juga dapat tercipta karena adanya ritual tertentu. Ritual yang terlepas dari rutinitas dapat membentuk sense of occasion.

Selain identitas, bentuk lain dimensi 'sense' adalah struktur (Ibid). Pada tempat dengan skala kecil, struktur yang dimaksud adalah keterkaitan antara satu tempat dengan tempat lain. Adapun pada ruang dengan skala yang lebih besar, hal tersebut berupa sense of orientation yang dirasakan melalui penataan fitur kota yang tepat proporsi dan tepat guna. Hal ini akan memengaruhi ingatan manusia yang merasakannya. Jika ruang kota mampu memberikan kemudahan padanya untuk mencapai destinasi yang ia tuju, maka ruang kota tersebut dapat dengan mudah dicerap dan diingat.

Tidak hanya itu, struktur sebagai bentuk lain dimensi 'sense' juga muncul karena adanya dimensi waktu. Orientasi waktu turut andil dalam membentuk struktur kota. Namun, struktur tersebut tercipta bukan hanya dengan mendirikan menara jam di suatu plaza, tetapi juga dengan memaksimalkan bentuk fitur fisik kota yang statis, termasuk arsitektur. Kehadiran bangunan yang didirikan pada masa lampau mampu menciptakan kesan keberlanjutan masa lampau hingga masa kini. Apalagi jika terdapat ritual tertentu pada bangunan tersebut. Dalam kondisi ini, bangunan tua memberikan kesempatan kepada penggunanya untuk mencerap jejak-jejak masa lalu sekaligus meneruskan tradisi.

Identitas dan struktur sebagai bentuk sederhana dimensi 'sense' merupakan aspek 
yang memungkinkan kita merekam pola ruang dan waktu. Keduanya adalah level yang paling pertama dialami seseorang dalam menyelami ruang kota. Adapun hal yang lebih dalam dari identitas dan struktur adalah kualitas yang menghubungkan wujud kota dengan fitur lain di kehidupan kita, yaitu congruence, transparency, dan legibility (Ibid).

Congruence, atau kesesuaian wujud ruang atau tempat dengan persepsi kita, adalah kualitas yang dapat ditilik melalui pertanyaan mengenai fungsi formal suatu tempat oleh pengamat dan penggunanya. Adapun transparency atau keterbukaan adalah tingkatan seseorang dapat secara langsung merasakan beragam fungsi, aktivitas, serta proses sosial dan natural yang tercipta pada suatu tempat. Selain itu, legibility atau keterbacaan juga menjadi hal yang dapat mengukur apakah suatu tempat mampu 'berkomunikasi' secara akurat dengan penggunanya melalui simbol-simbol di fitur fisiknya. Legibility erat kaitannya dengan semiotik-ilmu mengenai tanda. Dengan kata lain, konstruksi sosial dan budaya mengenai suatu fitur kota tentu memengaruhi pemaknaannya.

Ketiga hal di atas-congruence, transparency, legibility -merupakan komponen yang mengaitkan fitur fisik kota, termasuk bangunan bersejarah, dengan nilai-nilai dan konsep nonspasial. Ketiganya dapat ditinjau untuk mengetahui apakah suatu bangunan bersejarah sesuai fungsi formalnya dengan keseharian penggunaannya dan mudah diakses serta dibaca oleh pengguna dan pengamatnya.

Dari penjelasan dimensi 'sense' tersebut dapat diketahui bahwa pengalaman dalam ruang kota, termasuk di sekitar bangunan bersejarah, dapat membentuk gambaran tertentu pada persepsi subjek yang merasakannya. Dalam kasus Masjid Jami Kali Pasir, merasakan ruang sekitarnya menjadi unik karena pengetahuan tentang masjid tertua dan statusnya sebagai bangunan cagar budaya kontradiktif dengan kehadirannya yang kurang mencolok. Hanya dengan menelusuri ruang sekitarnya, kita dapat benarbenar mengetahui apakah arsitektur Masjid Jami Kali pasir berkesan bagi warga dan pengunjung, hingga dapat membentuk sense of place and orientation.

\section{METODE PENELITIAN}

Untuk mengetahui nilai yang dapat dicerap dari arsitektur Masjid Jami Kali Pasir diperlukan penelusuran keseharian di dalam dan sekitar masjid dengan cara berjalan kaki. Saat berjalan kaki alat dan sistem indera kita dapat beradaptasi untuk menafsirkan hal-hal yang kita cerap (Gehl, 2010). Laju pejalan kaki memungkinkan kita untuk meninjau detail-detail di sekitar kita, termasuk bangunan, dan meresponsnya.

Tidak hanya itu, untuk mendukung pengalaman menyelami ruang di dan sekitar Masjid Jami Kali Pasir, dilakukan pula wawancara terstruktur dan penyebaran kuesioner pada 25 warga Kali Pasir, 25 warga di luar Kampung Kali Pasir, dan 25 pengunjung kawasan Pasar Lama dan sekitarnya. Wawancara dan kuesioner ini bertujuan untuk mencari tahu hal apa yang berkesan bagi responden terhadap kawasan Pasar Lama dan Masjid Jami Kali Pasir.

\section{HASIL DAN PEMBAHASAN}

Masjid Jami Kali Pasir terletak di Jalan Kali Pasir Indah, Kecamatan Sukasari, Kota Tangerang. Masjid ini terletak di kawasan yang terkenal dengan sebutan Pasar Lama. Pasar Lama memiliki ragam bangunan yang unik. Menurut Hendola dan Priadi, kawasan ini memiliki karakteristik 'serbaneka' - bangunan lama dan baru serta bangunan Tionghoa dan non-Tionghoa saling bersanding tanpa pengucilan satu sama lain (Hendola, 2017).

Sedikit meninjau elemen fisik arsitekturnya, Masjid Jami Kali pasir memiliki ukuran kurang lebih 14,5 m x 14,5 m, beratap limasan dengan puncak berukiran bunga emas, dan minaret di sampingnya. Di bagian depannya terdapat kompleks pemakaman yang menghadap Sungai Cisadane. Menurut catatan sejarah "Nyukcruk Galur Mapay Patilasan: Masjid Jami' Kali Pasir" yang disusun oleh DKM, Masjid Jami Kali Pasir memiliki beberapa bagian yang masih asli, yaitu empat pilar kayu jati, kubah ukiran mawar, kompleks makam tua para Tumenggung, dan mimbar imam (Dewan Kesejahteraan Masjid Jami Kali Pasir, 2016) (Gambar 3, dan 4). 


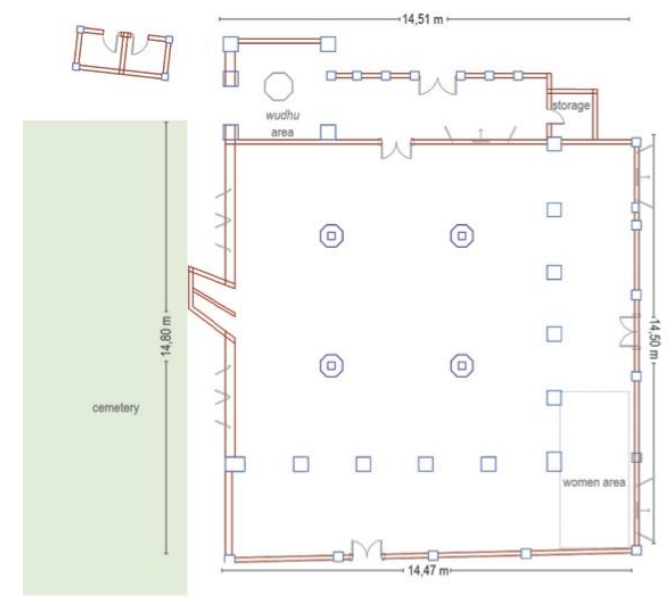

A U

Gambar 3. Denah Masjid Jami Kali Pasir

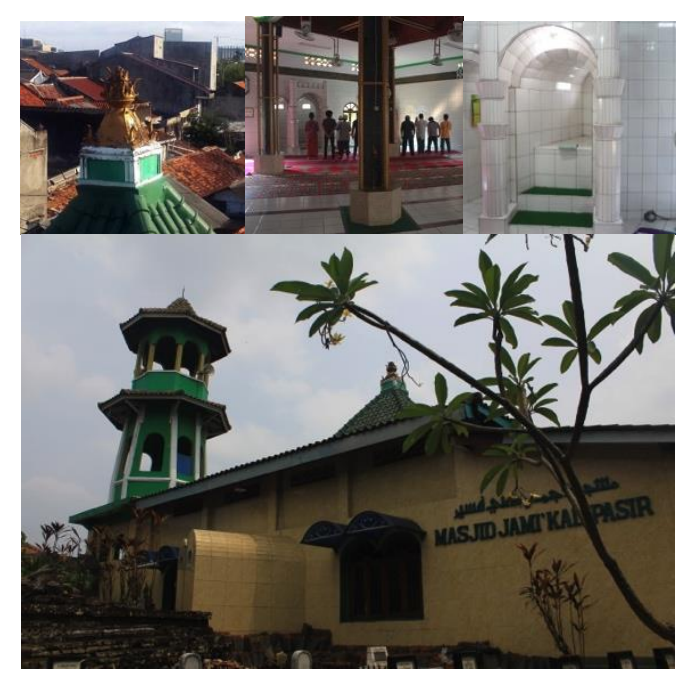

Gambar 4. Puncak Atap, Pilar Tua, Mimbar, dan Bagian Depan Masjid Jami Kali Pasir

Terdapat beberapa jalan untuk mencapai Masjid Jami Kali pasir. Dalam penelitian ini, penelusuran dilakukan melalui Jalan Cilame menuju Jalan Bakti Saham, lanjut ke Jalan Kali Pasir dan menelusuri gang-gang yang ada di sekitar Masjid Jami Kali Pasir.

\section{Berjalan Kaki ke Masjid Jami Kali Pasir: Dari Pecinan ke Gang-Gang}

Jalan Cilame adalah jalan yang langsung menghubungkan Jalan $\mathrm{Ki}$ Samaun dengan kawasan pecinan Pasar Lama. Ujung dari jalan ini adalah Jalan Bakti Saham di mana Klenteng Boen Tek Bio berdiri di depan sebuah pertigaan (Gambar 5).

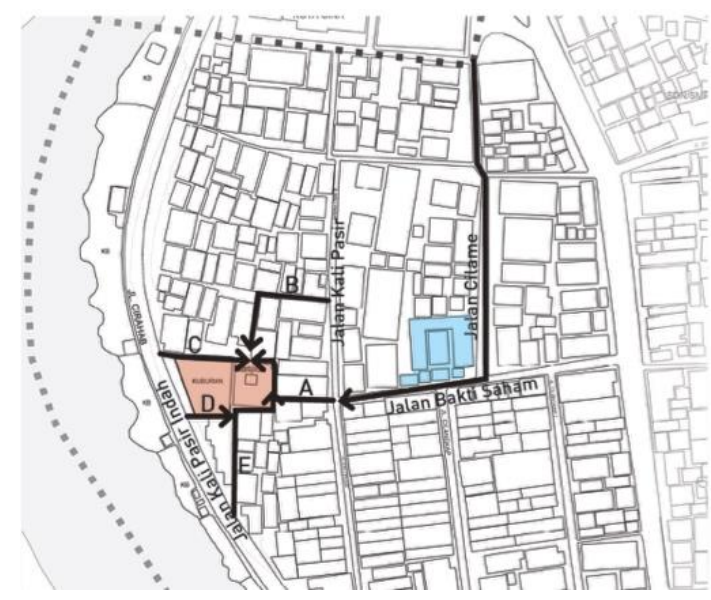

Gambar 5. Peta Jalur Penelusuran dan Lokasi Masjid Jami Kali Pasi [merah] dan Klenteng Boen Tek Bio [biru]

Dari Jalan Cilame menuju Jalan Bakti Saham terdapat rumah toko dan bangunan yang masih menyisakan ornamen dan bubungan atap arsitektur Tionghoa, termasuk Museum Benteng Heritage yang merupakan hasil restorasi salah satu hunian Tionghoa. Sementara meja dan stan pasar beserta sisa hasil jualan turut mewarnai jalan ini. Lebar Jalan Cilame kurang lebih 3 meter dengan bangunan setinggi satu hingga tiga lantai mengerangkai pandangan. Dengan adanya meja, gerobak, tenda, dan perkakas lainnya untuk menempatkan barang dagangan, Jalan Cilame terasa lebih sesak dari yang seharusnya.

Sampai di ujung, terdapat Jalan Bakti Saham yang ramai dengan barang dagangan, khususnya untuk makanan dan keperluan ibadah. Wangi dupa dari Klenteng Boen Tek Bio mulai terhirup dan bubungan atap arsitektur Tionghoa masih mendominasi pandangan. Pada ujung Jalan Bakti Saham terdapat bangun Tionghoa lama yang baru saja direstorasi, seolah mengakhiri perjalanan di kawasan pecinan.

Jalan Kali Pasir memiliki suasana yang berbeda dengan Jalan Cilame dan Jalan Bakti Saham. Rumah beratap pelana dan limasan dengan gaya arsitektur yang lebih kontemporer mewarnai ruang di jalan ini. Dari Jalan Bakti Saham ke Masjid Jami Kali Pasir terdapat dua gang. Gang pertama (A) langsung menuju ke pintu belakang masjid, sedangkan gang kedua (B) sedikit memutar menuju pintu utama masjid (Gambar 6). 


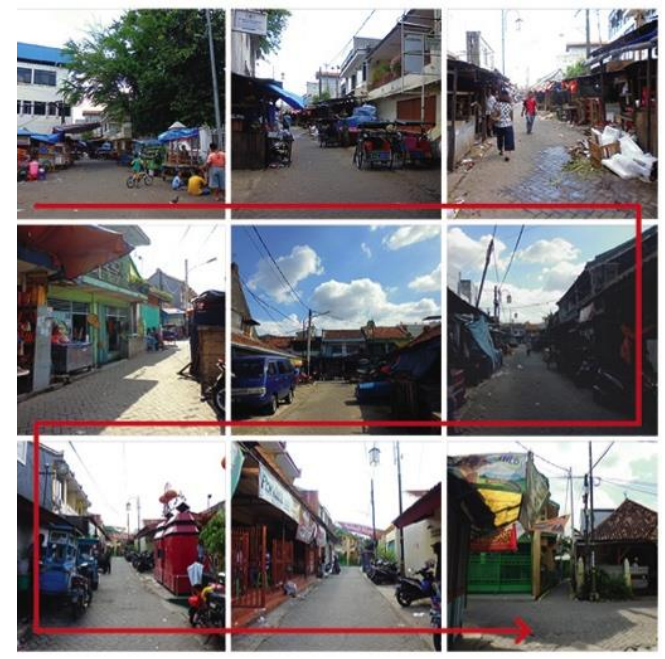

Gambar 6. Runutan Perjalanan dari Jalan Cilame ke Jalan Bakti Saham

Gang pertama memiliki lebar kurang lebih 1,2 meter dengan selokan di pinggirnya. Gang ini dikerangkai oleh bangunan satu hingga dua lantai di kanan dan kirinya. Dengan proporsi lebar jalan dan tinggi bangunan seperti itu, pandangan akan terpaku pada ujung gang. Dalam perjalanan ini ujung gang tersebut adalah dinding hijau Masjid Jami Kali pasir.

Kurang lebih 12 meter dari titik awal gang pertama, tampak pintu belakang Masjid Jami Kali Pasir. Bila pengamat mendongak sedikit, atap dengan ukiran bunga dan puncak minaret dapat terlihat. Selanjutnya terdapat jalan yang lebih luas, sekitar 3 meter, yang dihimpit oleh masjid dan bangunan serba guna. Ruang antarbangunan ini sering digunakan untuk beragam kegiatan sehari-hari oleh warga sekitar, seperti bermain bagi anak-anak, duduk-duduk dan bercengkerama, berjualan jajanan, dan kegiatan yang mendorong interaksi sosial lainnya.

Untuk mencapai pintu utama Masjid Jami Kali Pasir, perjalanan perlu dilanjutkan melalui jalan yang mengecil di ujung ruang antarbangunan tersebut. Setelah berkelok, pilarpilar dengan balok melengkung dapat terlihat. Pilar tersebut membatasi teras masjid dengan jalan. Pada bagian tengah barisan pilar ini terdapat pintu utama masjid. Jika pintu terbuka, tanpa masuk ke teras, sebagian ruang dalam masjid dengan pilar kayu di dalamnya tertampak (Gambar 7).

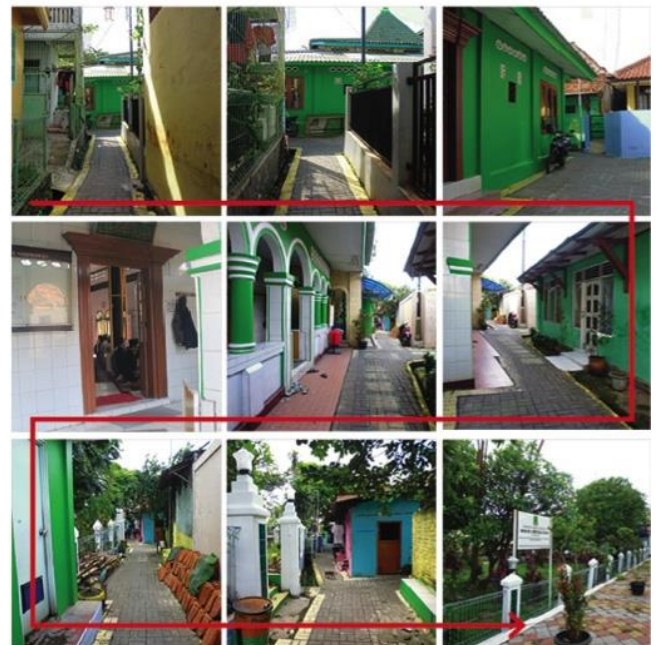

Gambar 7. Runutan Perjalanan dari Jalan Kali Pasir ke Gang A

Gang kedua memiliki proporsi lebar jalan dan ketinggian bangunan yang kurang lebih serupa dengan gang pertama. Gang ini juga menjadi tempat warga saling berinteraksi. Sebagian besar hunian di sepanjang gang ini berorientasi ke jalan, sehingga memudahkan warga untuk bercengkerama dengan tetangga.

Perjalanan dari gang kedua menuju Masjid Jami Kali Pasir perlu berbelok di pertigaan pertama. Setelah belok, jalan menuju masjid dikerangkai oleh tembok hunian yang mengarahkan pandangan ke dinding hijau masjid. Dengan melangkah maju kurang lebih tiga meter atap masjid dan sebagian menaranya dapat terlihat. Pada ujung gang ini tampak pilar teras masjid berjejer, serta tempat wudu di sampingnya (Gambar 8).

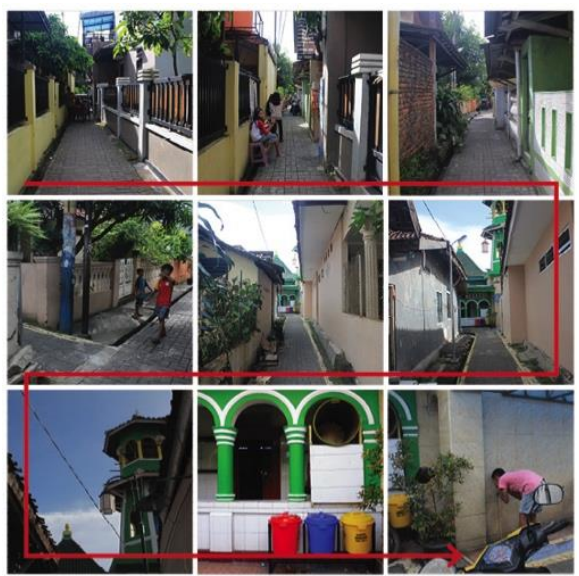

Gambar 8. Runutan Perjalanan dari Jalan Kali Pasir ke Gang B

Selain dari Jalan Kali Pasir, jalan menuju Masjid Jami Kali Pasir juga dapat dilalui dari 
Jalan Kali Pasir Indah. Dari jalan di pinggir Sungai Cisadane ini, ada tiga gang yang menjadi akses langsung ke masjid. Gang pertama (C) memanjang di bagian utara masjid, gang kedua (D) memanjang di bagian selatan pemakaman masjid dan menyambung ke gang ketiga (E) yang mengarahkan pejalan kaki ke masjid dari arah selatan.

Dari titik awal gang pertama dapat terlihat pemakaman depan Masjid Jami Kali Pasir. Pemakaman ini dirimbuni pepohonan yang menutupi sebagian muka bangunan (facade) masjid. Setelah turun melalui beberapa anak tangga, terdapat jalan selebar kurang lebih satu meter yang dibatasi oleh hunian satu lantai di sisi kiri dan pagar pemakaman di sisi kanan. Sekitar lima meter dari titik awal terdapat jalan masuk ke pemakaman tersebut.

Seperti gang-gang yang telah dibahas sebelumnya, gang ini juga memiliki lebar jalan yang tidak mencapai dua meter. Namun, adanya ruang terbuka pemakaman membuatnya terasa tidak sama sempit dengan gang-gang lainnya. Dari gang ini pula minaret masjid dapat terlihat lebih mendetail. Di bawah menara tersebut terdapat toilet umum dan tempat berwudu (Gambar 9).

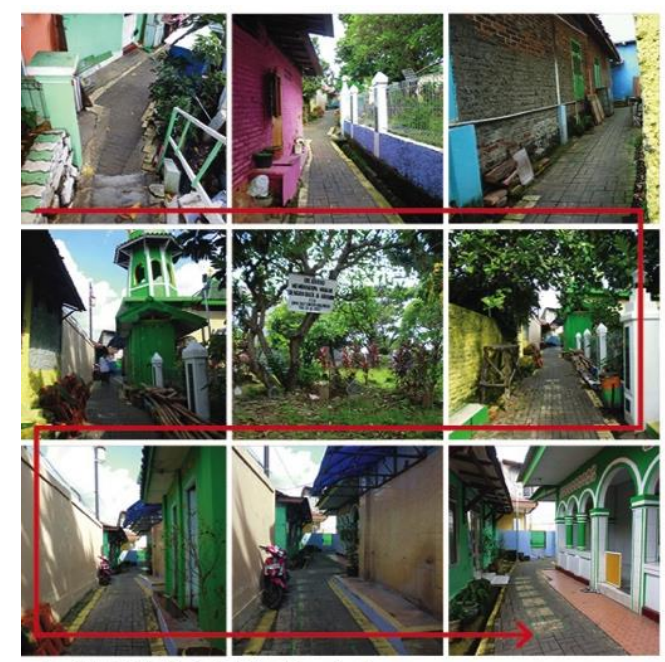

Gambar 9. Runutan Perjalanan dari Jalan Kali Pasir Indah ke Gang C

Gang kedua juga berbatasan dengan pemakaman. Namun, tidak seperti gang pertama, gang kedua terkesan lebih 'dingin'. Hal ini disebabkan pembatas lain dari gang kedua berupa tembok polos tanpa bukaan. Selain itu, ujung pemandangan gang ini juga kurang menarik perhatian, yaitu dinding hunian yang luruh di beberapa bagian.
Sementara pada titik awal gang ketiga pejalan kaki akan disambut dengan hunianhunian satu lantai. Dari trotoar Jalan Kali Pasir Indah yang letaknya lebih tinggi dari gang ini, dapat terlihat atap dan minaret Masjid Jami Kali Pasir di antara tembok tinggi dan atap-atap hunian tersebut. Orientasi hunian di gang ini memang ke arah jalan sesempit gang-gang lain yang telah dibahas sebelumnya. Saat menelusuri gang ini, jemuran, meja, alat memasak, dan perkakas rumah tangga lainnya dapat terlihat menggantung di dinding teras atau bahkan di dinding polos bangunan seberang hunian. Setelah berjalan sekitar 25 meter di antara hunian dan dinding tersebut, bagian selatan Masjid Jami Kali Pasir dapat terlihat (Gambar 10).

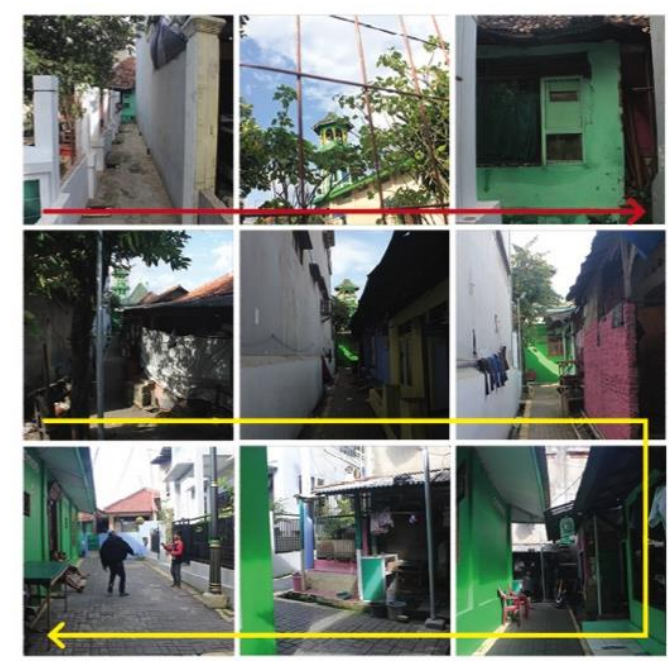

Gambar 10. Runutan Perjalanan dari Jalan Kali Pasir Indah ke Gang D [panah merah] dan Gang E [panah kuning]

Sampai di sini dapat diketahui bagaimana suasana di sekitar Masjid Jami Kali Pasir hanya dengan menelusuri jalan dan gang di sekitarnya. Secara umum perubahan paling signifikan saat menuju Masjid Jami Kali Pasir adalah di akhir Jalan Bakti Saham. Selain karena perbedaan gaya bangunan, lebarnya jalan memengaruhi pengalaman ruang pejalan kaki. Bagaimana kemudian runutan perjalanan menuju Masjid Jami Kali Pasir tersebut menunjukkan identitas, struktur, kecocokan (congruence), keterbukaan (transparency), dan keterbacaan (legibility) akan dibahas pada bagian selanjutnya. 
2. Struktur dan Identitas Kawasan Sekitar Masjid Jami Kali Pasir

Menilik struktur ruang kota kawasan Pasar Lama-Kali Pasir perlu meninjau peta kawasan ini. Hendola dan Priadi pernah membahas hal ini, bahwa struktur ruang Kampung Kali Pasir dan kawasan Pasar Lama sekitar Klenteng Boen Tek Bio berbeda (Hendola dan Priadi). Kawasan di sekitar Klenteng Boen Tek Bio ditata sesuai feng shui, sehingga jejaring ruang kotanya berupa grid. Adapun Kampung Kali Pasir memiliki jejaring yang lebih acak dengan orientasi bangunan yang tidak selalu ke satu arah (Gambar 11).
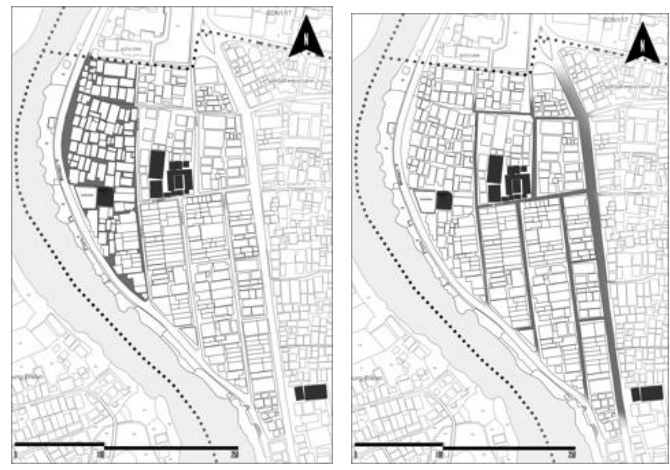

Gambar 11. [kiri] Jaringan Jalan Mengacak di Bagian Barat Jalan Kali Pasir, [kanan] Jaringan Jalan Teratur di Bagian Timur Jalan Kali Pasir Aumber: Hendola \& Priadi, 2016

Jika melihat dari sudut pandang pejalan kaki, perbedaan struktur ruang kawasan Pasar Lama-Kali Pasir terletak pada orientasi ruang serta bentuk dan gaya bangunan di sepanjang jejaringnya. Dapat dilihat pada Gambar 12, Jalan Cilame dan Jalan Bakti Saham cukup lebar bagi pejalan untuk mengidentifikasi bentuk dan fungsi bangunan di sepanjang jalan dan ujung jalan. Hal ini memberikan orientasi yang jelas bagi pejalan kaki dan memudahkan pengunjung untuk mengamati bangunan lama di jalan tersebut.

Adapun di gang-gang menuju Masjid Jami Kali Pasir, pejalan kaki akan kesulitan mengidentifikasi bentuk dan fungsi bangunan karena sempitnya jalan. Akan tetapi, sempitnya jalan tersebut tetap memberikan orientasi, meski tidak sejelas Jalan Bakti Saham. Orientasi pada gang-gang sekitar masjid terbentuk karena detail hunian yang rupa dan warnanya beragam dengan masjid sebagai pusatnya. Ditambah lagi gang-gang tersebut konsisten mengarah ke Sungai Cisadane. Namun, orientasi ini terbentuk secara personal bagi mereka yang kerap melewatinya. Bagi orang asing atau pengunjung, proporsi lebar jalan dan tinggi bangunan seperti yang telah dijelaskan akan menyulitkan untuk menerka secara pasti arah jalannya. Sebagaimana yang tertera pada Gambar 12, orientasi jalan menjadi lebih 'mengejutkan' bagi pengunjung karena ujung pandangan terbatas. Pada satu titik jalan terlihat lurus saja, tetapi beberapa meter ke depan ternyata ada percabangan, dan sebagainya.

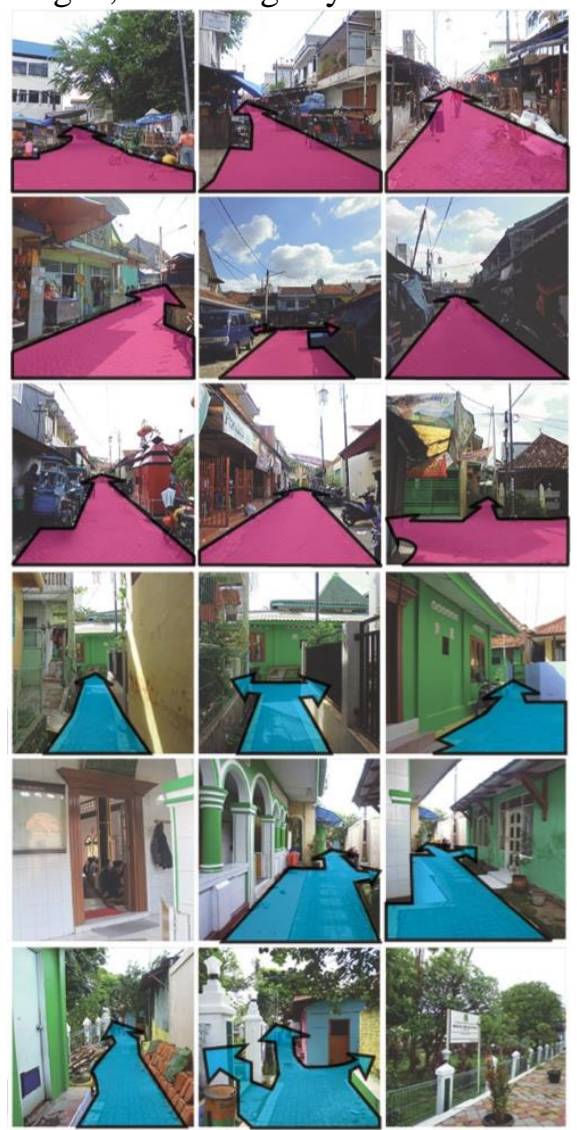

Gambar 12. [merah muda] Orientasi di Jalan Cilame-Jalan Bakti Saham, [biru] Orientasi di Jalan Kali Pasir-Gang A

Tidak hanya orientasi jalan, gaya dan bentuk bangunan menentukan persepsi mengenai struktur ruang kota di kawasan Pasar Lama-Kali Pasir. Dari pengamatan penulis saat berjalan kaki, Jalan Bakti Saham dan Jalan Cilame dapat disebut sebagai pecinan karena ditandai oleh bubungan atap arsitektur Tionghoa. Bubungan atap ini tidak hanya terdapat pada satu-dua bangunan saja, tetapi juga berbaris di beberapa titik. repetisi bubungan atap tersebut membentuk ciri khas jalan ini. 
Selain itu, kehadiran Klenteng Boen Tek Bio di depan pertigaan Jalan Bakti Saham-Jalan Cilangkap juga dapat menjadi identitas kawasan pecinan Pasar Lama. Identitas, sebagaimana Lynch utarakan, merupakan citra yang muncul dari suatu entitas yang unik (Lynch, 1960). Letak Klenteng Boen Tek Bio yang mudah dilihat dan fungsinya yang penting, yakni sebagai tempat ibadah umat Konghucu dan Budha, mempermudah warga dan pengunjung untuk mengingat kehadirannya dan menjadikannya tengara.

Pada sisi lain, bangunan di Jalan Kali Pasir dan gang-gang di sekitar Masjid Jami Kali Pasir tidak memiliki fitur unik yang membedakannya dengan perumahan lain pada umumnya. Sementara itu, arsitektur Masjid Jami Kali Pasir secara keseluruhan tidak dapat disebut dalam satu langgam, sebagaimana Klenteng Boen Tek Bio yang merepresentasikan pecinan. Misalnya, ukiran bunga di puncak atap masjid banyak ditemukan pada masjid-masjid di daerah Cirebon, sementara empat pilar di tengah serupa soko guru pada arsitektur Jawa (Lukito). Akan tetapi, identitas Kampung Kali Pasir justru muncul karena kehadiran masjid ini. Masjid Jami Kali Pasir yang terletak berdekatan dengan Klenteng Boen Tek Bio menekankan perbedaan dari kawasan pecinan dan non-pecinan (Hendola \& Priadi).

Keterkaitan Masjid Jami Kali Pasir dengan Klenteng Boen Tek Bio tidak hanya dirasakan oleh penulis, tetapi juga warga dan pengunjung kawasan Pasar Lama. Data dari kuesioner menunjukkan bahwa 10 dari 21 pengunjung yang menyatakan pernah ke kawasan Pasar Lama menjawab tempat ibadah adalah hal yang paling diingat saat mereka berkunjung. Sebagian besar di antaranya menuturkan alasan yang mengindikasikan bahwa kedekatan dua tempat ibadah berbeda umat tersebut menjadi bukti toleransi agama dan budaya. Selain itu, dari 25 warga sekitar kawasan Pasar Lama, 10 orang di antaranya juga menjawab tempat ibadah adalah hal yang paling berkesan, sementara 13 di antaranya menuturkan bahwa toleransi budaya dan agama adalah ciri khas kawasan pusaka ini. Adapun dari 25 responden warga Kali Pasir, 15 menjawab tempat ibadah adalah hal yang paling berkesan dan 16 mengatakan toleransi agama dan budaya adalah ciri khas kawasan pusaka Pasar Lama.

Sampai di sini dapat disimpulkan bahwa struktur dan pengalaman ruang di sekitar Masjid
Jami Kali Pasir berbeda dengan di Jalan Cilame-Jalan Bakti Saham. Perbedaan ini ditekankan dengan kehadiran Masjid Jami Kali Pasir dan Klenteng Boen Tek Bio. Tidak hanya itu, karena kedekatan lokasi kedua tempat ibadah ini, perbedaan tersebut tidak dilihat sebagai suatu pemisahan oleh lebih dari 50\% warga dan pengunjung yang diwawancarai, melainkan bagian dari toleransi yang menjadi ciri khas kawasan pusaka Pasar Lama Tangerang.

\section{Makna Masjid Jami Kali Pasir: Kecocokan (Congruence), Keterbukaan (Transparency), dan Keterbacaan (Legibility) \\ Menilik bagaimana suatu bangunan} bermakna atau menunjukkan nilainya pada suatu ruang kota tidak terlepas dari subjek yang mengalaminya, apakah ia dapat menikmati atau merasakannya dengan mudah. Dalam hal ini, kualitas tersebut berupa kecocokan (congruence) fungsi ruang dan bangunan di Jalan Cilame-Jalan Bakti Saham dan gang-gang di sekitar Masjid Jami Kali Pasir terhadap persepsi orang yang mengalami ruangnya, keterbukaan (transparency) jalan dan gang tersebut untuk diakses dan dirasakan oleh siapa pun, serta keterbacaan (legibility) ruang dan bangunan di jalan tersebut, mencakup simbol dan mitos terkait, yang ditangkap oleh pengunjung ataupun warga.

Mengingat penelitian ini terfokus pada nilai Masjid Jami Kali Pasir, maka perlu ditinjau bagaimana permeabilitas menuju masjid ini. Secara umum siapa pun boleh mengunjungi Masjid Jami Kali Pasir, baik untuk beribadah, berziarah, ataupun hal lain, selama masih menghormati ritual keagamaan di dalamnya. Meskipun demikian, seperti yang telah diketahui, untuk menuju masjid ini perlu menelusuri gang-gang yang melewati hunian warga. Hal ini dapat meberikan rasa ragu bagi orang asing untuk melewatinya, sekaligus menjadi elemen yang menantang atau mengejutkan bagi yang memiliki intensi untuk ke masjid. Adapun bagi warga Kali Pasir, hal ini dapat memudahkan mereka berinteraksi dengan tetangga dan menjadikan Masjid Jami Kali Pasir sebagai pusat ibadahnya.

Pada acara islami tertentu, jalan sempit di sekitar masjid juga dimanfaatkan oleh warga untuk mendukung jalannya acara tersebut. Pada Idul Adha, misalnya, jalan di sekitar Masjid Jami Kali Pasir digunakan untuk pemotongan 
dan pembersihan daging kurban. Siapa saja boleh menyaksikan dan membantu proses ini. Tidak hanya itu, Masjid Jami Kali Pasir juga memiliki tradisi memperingati penyebaran agama Islam di setiap Hari Maulid Nabi SAW yang bernama 'Arakan Perahu'. Acara Arakan Perahu biasanya dilakukan oleh warga Kali Pasir dengan berderap mengarak perahu buatan mengelilingi area Pasar Lama dan berhenti di Masjid Jami Kali Pasir. Pada saat inilah eksistensi masjid kecil tersembunyi ini 'meluas' (Ibid).

Dari pemaparan di atas dapat diketahui bahwa Masjid Jami Kali Pasir mampu memberikan sense of place karena fungsinya sebagai tempat ibadah yang bukan saja memfasilitasi rutinitas dalam menjalankan ritual keagamaan, tetapi juga memberikan sense of occasion dengan adanya kegiatan yang sudah menjadi tradisi, seperti Arakan Perahu. Fungsinya sebagai tempat ibadah dan letaknya yang dapat diakses dari berbagai arah meski tertutup oleh bangunan lain memberikan sense of orientation.

Meski kesimpulan sederhana di atas masuk akal, persepsi setiap orang terhadap Masjid Jami Kali Pasir dapat saja berbeda. Dari seluruh responden yang mengisi kuesioner dan diwawancarai (75 responden), 42 orang sudah pernah mengunjungi Masjid Jami Kali Pasir dan 29 di antaranya mengatakan bahwa nilai sejarah merupakan alasan mengapa masjid ini bermakna penting. Meninjau lebih dalam data ini, dari 25 warga Kali Pasir yang diwawancarai, kebanyakan (21 warga) menjawab menggunakan Masjid Jami Kali Pasir sebagai tempat salat. Sebanyak 13 dari 25 responden tersebut juga menganggap bagian yang berkesan dari Masjid Jami Kali Pasir adalah empat pilar tuanya. Adapun dari 25 warga luar kampung Kali Pasir yang diwawancarai, 21 di antaranya menganggap masjid tersebut penting, terlepas mereka sudah pernah mengunjunginya atau belum. Sebanyak 8 dari 12 warga sekitar Kali Pasir yang pernah berkunjung mengutarakan Masjid Jami Kali Pasir bermakna penting karena nilai sejarahnya.

Jika data di atas dikaitkan dengan persoalan kecocokan (congruence) pada Masjid Jami Kali Pasir, dapat disimpulkan bahwa persepsi responden tentang Masjid Jami Kali Pasir sebagai tempat ibadah memang sesuai dengan fungsinya. Namun tidak sampai di situ, cerita dan sejarah tentang masjid ini turut diterima oleh para responden. Oleh karena itu, meskipun letaknya tersembunyi, Masjid Jami Kali Pasir bermakna penting bagi mereka.

Adapun dari segi keterbukaan (transparency), Masjid Jami Kali Pasir sebenarnya dapat diakses oleh siapa pun. Warga Kali Pasir dengan mudah berinteraksi di sekitar masjid ini. Pengunjung, meskipun harus melewati gang-gang kecil, juga tidak dilarang untuk berkunjung. Selain itu, kegiatan keagamaan yang dilaksanakan di masjid juga boleh dihadiri oleh siapa saja. Pada acara Arakan Perahu, misalnya, semua orang boleh ikut mengarak perahu dan turut mengaji. Jadi, bangunan Masjid Jami Kali Pasir yang tersembunyi tidak membuat berbagai kegiatan yang terkait dengannya, baik yang sifatnya rutin menyehari ataupun yang diadakan setahun sekali, luput dari perhatian warga dan pengunjung.

Dari segi keterbacaan (legibility), Masjid Jami Kali Pasir sebenarnya tidak terlepas dari struktur dan identitas kawasan Pasar Lama-Kali Pasir. Seperti yang telah dibahas sebelumnya, Masjid Jami Kali Pasir kerap dihubungkan dengan Klenteng Boen Tek Bio karena perbedaannya dan lokasi keduanya yang berdekatan. Hal ini juga terjadi karena adanya sistem semiotik yang memengaruhi persepsi warga dan pengunjung. Minaret masjid, misalnya. Bentuk oktagonal dan atapnya mengingatkan pengamatnya pada pagoda, salah satu konstruksi yang signifikan pada arsitektur Tionghoa. Oleh karena terletak di sebuah masjid-bangunan non-Tionghoa-maka muncul pengetahuan akan ornamen arsitektur Tionghoa di bangunan non-Tionghoa yang kemudian menjadi tanda (sign) bagi 'toleransi budaya dan agama' (Ibid).

\section{KESIMPULAN: NILAI MASJID JAMI KALI PASIR SEBAGAI BANGUNAN CAGAR BUDAYA}

Dari penelusuran dengan berjalan kaki di atas, ada beberapa hal yang dapat disimpulkan. Yang pertama adalah struktur kampung Kali Pasir dan kawasan Pasar Lama berbeda satu sama lain, dengan Masjid Jami Kali Pasir dan Klenteng Boen Tek Bio sebagai tengara di masing-masing lokasi. Kedua, terdapat kecocokan (congruence) antara fungsi Masjid Jami Kali Pasir sebagai tempat ibadah dengan 
persepsi warga. Akan tetapi, tidak hanya itu, Masjid Jami Kali Pasir juga dianggap bermakna penting karena nilai sejarahnya, meskipun belum didukung data sejarah yang sahih. Ketiga, kemudahannya untuk diakses dan diawasi (transparency), membuat Masjid Jami Kali Pasir berkesan, khususnya bagi warga Kali Pasir. Keempat, letak Masjid Jami Kali Pasir yang berdekatan dengan Klenteng Boen Tek Bio juga dibaca (legibility) sebagai bentuk toleransi umat beragama.

Keempat kesimpulan ini menunjukkan bahwa arsitektur Masjid Jami Kali Pasir tidak hadir sebagai entitas yang mendominasi kawasan sekitarnya, yaitu kawasan pusaka Pasar Lama. Dalam skala kawasan, nilai sejarah Masjid Jami Kali Pasir dan keterkaitannya dengan pecinan lebih menggaung ketimbang elemen arsitekturnya. Adapun dalam skala yang lebih kecil, yakni di kampung Kali Pasir, bangunan Masjid Jami Kali Pasir dapat memberikan orientasi gang-gang kecil di sekitarnya karena fungsinya sebagai tempat ibadah dan tempat diadakannya acara keagamaan yang telah menjadi tradisi. Dapat dikatakan bahwa sejarah, tempat ibadah, dan tradisi merupakan hal yang paling signifikan dari Masjid Jami Kali Pasir dan turut memengaruhi citra lingkungan sekitarnya.

Meskipun demikian, temuan ini tidak berarti bahwa arsitektur Masjid Jami Kali Pasir tidak perlu dilestarikan. Salah satu nilai yang penting untuk ditinjau dalam melestarikan sebuah bangunan bersejarah adalah nilai emosional yang mencakup hal simbolik dan nilai spiritual bangunan [20]. Dalam kasus ini, Masjid Jami Kali Pasir menjadi entitas yang dianggap penting karena nilai spiritualnyaberkaitan dengan agama, tradisi, dan memiliki legenda tersendiri-termasuk konteksnya yang berdekatan dengan pecinan. Nilai spiritual yang muncul dari kesederhanaan bangunan masjid justru perlu dilestarikan untuk mempertahankan lokalitas Kali Pasir dan menguatkan citra 'serbaneka' kawasan pusaka Pasar Lama. Namun, pelestarian ini perlu dilakukan dengan tepat agar nilai sejarahnya tidak berkurang. Tanpa melestarikan masjid yang dianggap tertua ini dengan tepat, kesalahan persepsi soal sejarah Islam di Tangerang juga dapat terjadi.

Tidak sampai di situ, penelitian ini juga menunjukkan bahwa nilai suatu bangunan bersejarah tidak hanya terfokus pada umur, bentuk, dan langgam bangunannya saja, tetapi juga pengalaman di ruang sekitarnya. Dengan merasakan runutan perjalanan di sekitar Masjid Jami Kali Pasir, penulis dapat mengetahui bagaimana arsitektur masjid ini turut membentuk karakteristik kawasan pusaka Pasar Lama, khususnya dalam persepsi warga dan pengunjung. Keterkaitan ini dapat menjadi langkah awal pelestarian, tidak hanya pada arsitektur Masjid Jami Kali Pasir, tetapi juga kawasan pusaka Pasar Lama.

\section{Ucapan Terima Kasih}

Tulisan ini tidak akan rampung tanpa bantuan dari beberapa pihak. Oleh karena itu, penulis menghaturkan ucapan terima kasih kepada Universitas Pembangunan Jaya (UPJ) yang telah memberikan hibah penelitian fundamental sehingga penelitian ini dapat dilaksanakan; Ade Aji Prasetyo, Yudhi Priambodo Nugroho, dan Yoga Aditama Nurcahyo yang turut membantu pengambilan data penelitian; Muhammad Damm yang telah menjadi teman diskusi dan membantu mengoreksi tulisan ini; kolega dosen Program Studi Arsitektur UPJ dan keluarga tercinta yang terus mendukung; serta panitia Seminar Nasional II Departemen Arsitektur Universitas Sumatera Utara yang telah memberikan kesempatan kepada penulis.

\section{Daftar Pustaka}

Accuracy, International Journal of Heritage Architecture, Vol. 1, No.3, 355-364.

Dewan Kesejahteraan Masjid Jami Kali Pasir, Nyukcruk Galur Mapay Patilasan: Masjid Jami' Kali Pasir, Kota Tangerang: 2016.

Feilden, B.M. (2003) Conservation of Historic Buildings, Oxford: Architectural Press, hlm. 1.

Feilden, B.M., op.cit. hlm. iii.

Gehl, J. (2010) Cities for People, Washington: Island Press.

Hendola, F., Priadi, A. J. (2017) Masjid Jami Kali Pasir: In Between 'Myth' and a Need for Historical. 
Keputusan Walikota Nomor 430/kep.337Disporbudpar/2011 tertanggal 25 Agustus 2011.

Hendola, F., Priadi, A. J., op.cit.

Ibid., hlm. 131-134.

Ibid., hlm. 134.

Ibid., hlm. 138-140.

Kota Tangerang Kenalkan Sembilan Cagar Budaya. 2016. (http://nasional.republika.co.id/berita/nasi onal/jabodetabeknasional/16/05/17/o7b0ha366-kotatangerang-kenalkan-sembilan-cagarbudaya), diakses 28 Desember, 2016.

Lukito, Y., Asy Syahid, M. A., The Conservation of Kali Pasir Jami' Mosque in Tangerang, Banten, INSIST, Vol.2, Ed. $1,2017$.

Lynch, K. (1981) Good City Form, Massachussets: MIT Press., hlm. 131.

Lynch, K. (1960) Image of the City, Massachussets: MIT Press.

Lukito, Y., Asy Syahid, M. A., op.cit.

Ibid.

Ibid.

Masjid Jami Kalipasir, Bukti Akulturasi dan Kerukunan Beragama. 2014. (http://nasional.republika.co.id/berita/nasi onal/jabodetabeknasional/16/05/17/o7b0ha366-kotatangerang-kenalkan-sembilan-cagarbudaya), diakses pada 23 Oktober 2015. 